\title{
工業用純 $\mathrm{Al}$ 板に現われる二三の現象について（第 3 報） 中 間 加熱 の 影 響
}

池 野 佾 志*

Takashi Ikeno : Studies on Industrial Pure Al Sheets (III). On the Effect of Interval Heating on the Grain Size and Mechanical Properties of 2s Sheets.

The effect of the heating temperature after hot-rolling upon the recrystallization in cold-rolled $0.5 \mathrm{~mm}$ thick $2 \mathrm{~s}$ sheets was studied. The results obtained may be summarised as follows: (1) The recrystallization grain after hot-rolling becomes finer in size with the increase of hotrolling degree and the rise of interval heating temperature. (2) The recrystallization temperature becomes higher with the decrease of the degree of cold-rolling degree and the rise of the interval heating temperature even when the degree of cold-rolling is similar. (3) When the grain size of plates before cold-rolling is finer, the recrystallized grains also becomes finer. (4) As the degree of hot-rolling increase or that of cold-rolling decreases, the mechanical properties of recrystallized sheets becomes more isotropic.

(Received September 24, 1953)

\section{I. 緒}

著者は第 1 報(1)において高溫加工の條件が冷間加工板の 再結晶現象に著しく影䇾することを明にした. 本報告では さらに深絞り用 $\mathrm{Al}$ 板に適する素板を作るといら觀默に基 いて高溫加工終了時の板の厚さとそれ以後に抬ける冷間加 工度の影響，さらに中間燒鈍の影響などについて檢討した 結果を取り扱ら。

* 北陸輕金屬工業株式會社技術課

（1）池野，橫本, 野原, 本誌, 17(1953), 292.

\section{II. 苴 驗 方 法}

使用した試料は $\mathrm{Fe} 0.58 \%$ ， Si $0.15 \%$ 拈よび $\mathrm{Cu}$ $0.07 \%$ からなる $99.2 \% \mathrm{Al}$ で，鑄造前に $\mathrm{Cl}_{2}$ 處理を行 い, 充分脫ガスした，鑄达溫度 $700^{\circ}$ 抢よび金型溫度 $350^{\circ}$ として tilting mould に鑄达み, 厚さ $57 \mathrm{~mm} 14 \mathrm{~kg}$ のスラプとした・試料の調製方法は Table 1 に示すよ5 で，同一厚さの仕上板を作る場合の熱間嫄延板の厚さの變 化と，これに中間燒鈍を施行した場合の仕上り板性能變化 の模樣を追求した.すなわち, Table 1に示すような最終0.5. $\mathrm{mm}$ 板の二三の性質について比較檢討したわけである. 
Table 1

\begin{tabular}{|c|c|c|c|c|c|c|c|c|c|}
\hline \multirow{3}{*}{$\begin{array}{l}\text { No. of } \\
\text { specimens }\end{array}$} & \multirow{3}{*}{$\begin{array}{r}\text { Original } \\
\text { materials }\end{array}$} & \multicolumn{8}{|c|}{ Process } \\
\hline & & Hot & roll & $\mathrm{Pla}$ & ates* & Interval & heating & Cold & oll** \\
\hline & & $\begin{array}{c}\text { Temp: } \\
{ }^{\circ} \mathrm{C}\end{array}$ & $\mathrm{hr}$ & $\begin{array}{c}\text { Thickness } \\
\text { mm }\end{array}$ & $\underset{\%}{\text { Keduction }}$ & ${ }^{\text {Temp. }}$ & $\mathrm{hr}$ & $\begin{array}{c}\text { Thickness } \\
\text { mm }\end{array}$ & $\underset{\%}{\text { Reduction }}$ \\
\hline $\begin{array}{r}1 \\
2 \\
3 \\
4 \\
5 \\
6 \\
7 \\
8 \\
9 \\
10 \\
11 \\
12\end{array}$ & 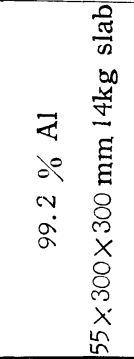 & 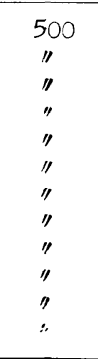 & $\begin{array}{l}4 \\
\text { " } \\
\text { " } \\
\text { " } \\
\text { " } \\
\text { " } \\
\text { " } \\
\text { " } \\
\text { " } \\
\text { " }\end{array}$ & $\begin{array}{l}8 \\
\text { " } \\
\text { " } \\
\text { " } \\
6 \\
\text { " } \\
\text { " } \\
4 \\
4 \\
\text { " } \\
\text { " }\end{array}$ & 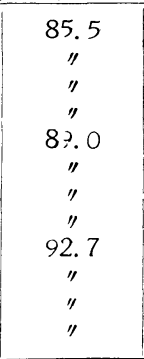 & $\begin{array}{l}\overline{400} \\
500 \\
550 \\
\overline{400} \\
500 \\
550 \\
\overline{400} \\
500 \\
550\end{array}$ & $\begin{array}{c}4 \\
" \\
" 1 \\
-4 \\
" 1 \\
" 1 \\
4 \\
" 1\end{array}$ & $\begin{array}{l}0.5 \\
\prime \prime \\
" 1 \\
\prime \prime \\
\prime \prime \\
" 1 \\
" 1 \\
" 1 \\
" 1 \\
" 1\end{array}$ & $\begin{array}{c}93.75 \\
\text { "' } \\
\text { " } \\
\text { "' } \\
91.66 \\
\text { " } \\
\text { "' } \\
87.50 \\
\text { " } \\
\text { " } \\
\text { " }\end{array}$ \\
\hline
\end{tabular}

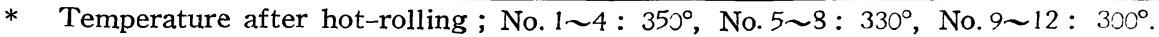

** Direction of cold rolling is crosswise for one of not-rolling.

\section{III. 宽 験 結 果}

\section{1. 高盜加エ材について}

鑄塊は同一つ湯を使椆して，同一條件で鑄造し, casting structure にも大差ないことを碓認した後試料とした.

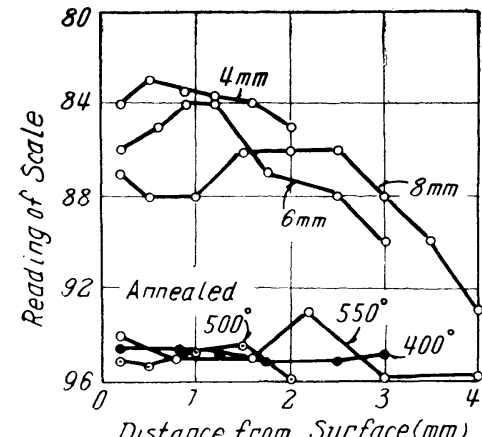

Fig. 1 Microhardness change of hot rolled plates. $500^{\circ}$ で 4 時閒 加熱した後高溫 加工して仕上げ た 8,6 扤よび $4 \mathrm{~mm}$ 板入試料 迦面つミク口硬 度を测定すると

Fig 1 に示す よらになり, 各 試料とも中心部 の方の硬度が低 下しているが，
火延板の厚いもの活どその傾问が强く, 全體としての硬度 值は薄いもの汪ど高くなつている. これらを 400〜 550 で 燒鈍すると多少湘定むらはあるが，ほが一定值に落付いて

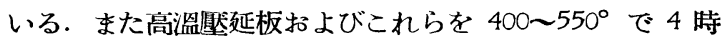
間加熱した後の顯微鏡組織を示すと Photo. 1 のよちで, 何れの場合にも $400^{\circ}$ 以上で再結晶していて, その結晶粒 の大いさは熱間加工度の大いほど，また加熱溫度の高い方 で微細になつている. 前者は板厚が薄くなるほど溫度降下 が大きく，冷間加エの影響をより多く受けるためと解さ れ，後者は加熱速度に影響され，功加熱溫度が再結晶溫 度に近い汪ど粗大となるといら事實 ${ }^{(2)}$ から解釋される. (燒 鈍はすべて宾氣浴爐で行い，豫め所定溫度に維持した中に 投入した）な技，Photo 1 で高溫加工度の小さい方で加 工時再結晶 (中心部) の傾向が見られるが, 加工度が大き くなると溫度降下が大きいために鍛鍊されて組織憎狀に 流れている. Photo. 2 は化合物粒子と再結晶粒の相對的 關係を示したもので, 再結晶粒は壓延方向に沿万て良く發 (2) 大日方, 畑, 本誌, 6(1942), 258.
達し，髯延方向と直角な方向では線狀に流れて連なつてい る第二相成分の位置で妨害されて，發達が止をり，粒狀が 細長くなつている模榚が良く制る.この傾向は加工度の低 い中心部に括いて，さらに熱間加工度の低い範喡で顯著と なる. $400^{\circ}$ 以上で再結晶することは, 高溫加工終了溫度 と考え合わせて從來の結果と矛盾しない.

\section{2. 冷間哈延板について}

前記 3 種つ板厚の高溫加工板を冷間で淔解に狀延して, すべて $0.5 \mathrm{~mm}$ 厚さの板に仕上げた. それぞれについ て，1特間一定として種々の溫度に加熱し，機械的性質の 變化を測定すると，Fig. 2〜4 に示すようになる. また， 圖中には顯微鏡組織の觀察によつて，再結晶溫度を調べた 結果を矢印で記入してある。これを見ると中間加熱溫度が 高いほど，再結晶溫度が高くなり，中間加熱溫度が低い方 で (中間加熱しないものではより一穈) 機㭜的性質回復の 速度が早くなつていて，特に冷間加工度の小さいおで顯著 である．伸つ值は冷間加工度が小さい方で中間加熱溫度の 高い方で良くなつているが，冷間加工度が大きく 90 \% 以 上になると却つて惡くなつている (Fig. 2〜4). しかるに， 同圖中に示すェリクセン值怯常に中閒加熱溫度が高い方で より高い値を示しているが，しかし，令間加工度の大小に よつてはその值に相逜が見られない，な扣，中間燒鈍條件 の相違と再結晶溫度との關係を圖示すると，Fig.5 のよ らになり，冷間加工度が小さいほど，再結晶溫度が高くな のは當然であるが，中間加熱溫度の影響は特琵で, 高溫加 工溫度の影響(1)と良く似ている。

\section{3. 再結晶粒度について}

$350^{\circ} \sim 1$ 特間加熱後, 再結晶粒度在調べてみると, Photo. 3 扣よび Fig.6 のよ5になり，冷間加工度が大き いほど再結晶粒度が小さくなるのは勿論であるが, Photo. 3 からわかるよらに, 中間加熱を行わないものが最も微細 （冷間加王度が大きくなるためであろち）となるが，中間 加熱した場合には加熱溫度が高い方でより微細となり，中 間加熱特の再結晶粒が大きいほど, 冷間加工後の再結晶粒 も粗大となり,これはあたかも鑄塊組織つ大小が再結晶粒 
度におよぼす影響とその傾向を一にする(3)．亮溫加工板の 再結晶粒度と冷間加工板のそれとの關係を示すと Fig. 6
$78.5 \%$ の線で異方性は減少して扢り，中間燒鈍溫度が高 いほど良好となつている。しかるに，冷間加工度が高くな

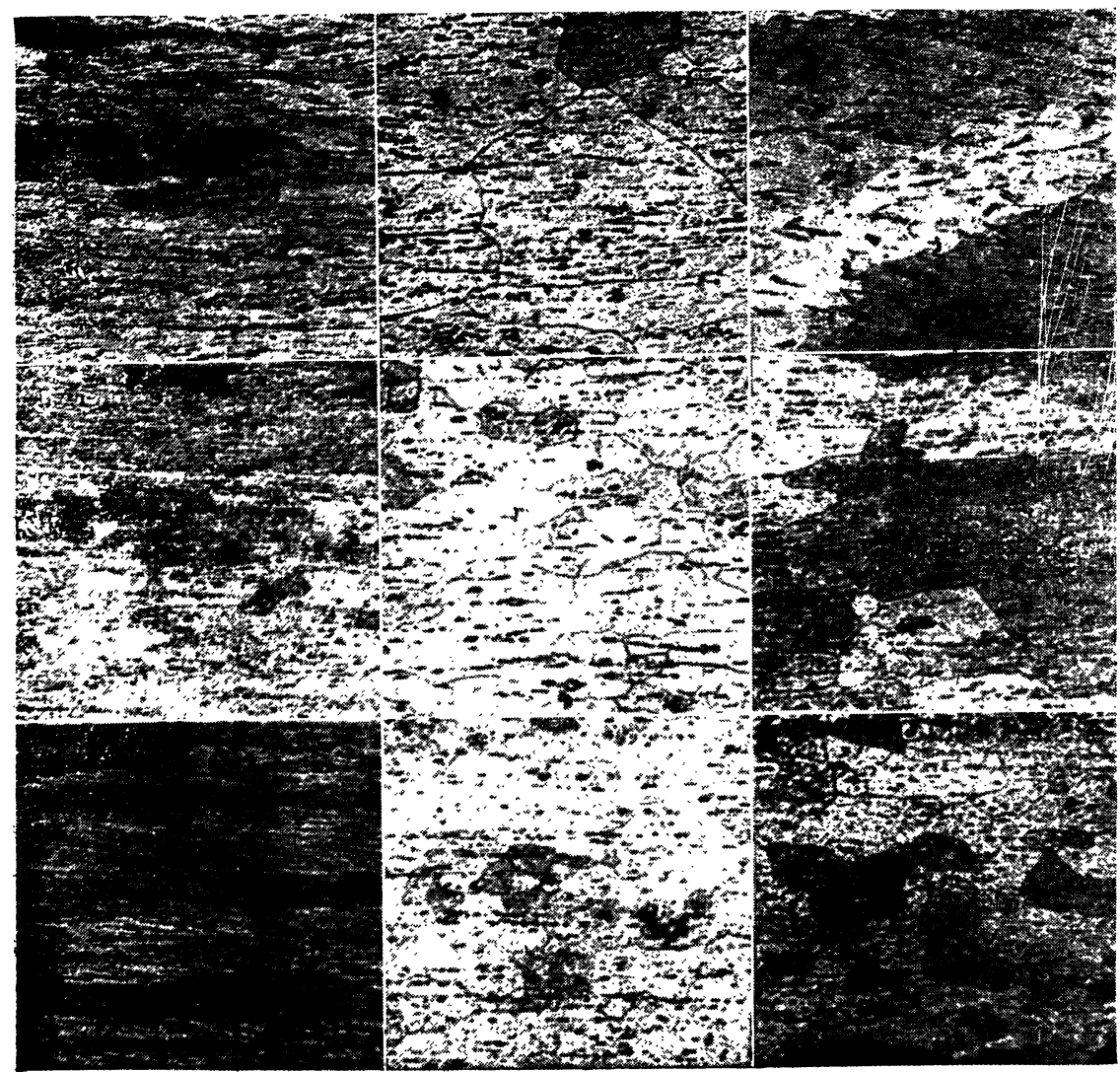

Photo. 1 Microstructures of hot rolled plates.
From left (at $8 \mathrm{~mm}$ plates )

as rolled, $550^{\circ} \sim 4 \mathrm{hrs}$ and $400^{\circ} \sim 4 \mathrm{hrs}$

From left (at $6 \mathrm{~mm}$ plates)

as rolled, $550^{\circ} \sim 4 \mathrm{hrs}$ and $500^{\circ} \sim 4 \mathrm{hrs}$

From left (at $4 \mathrm{~mm}$ plates)

as rolled, $500^{\circ} \sim 4 \mathrm{hrs}$ and $400^{\circ} \sim \mathrm{hrs}$

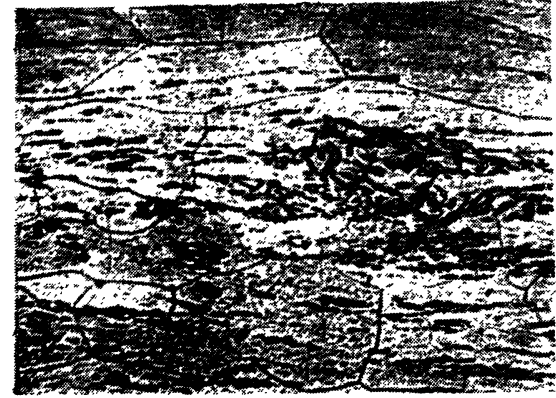

Photo. 2 Microstructure at center part of $8 \mathrm{~mm}$ plates after hcating at $500^{\circ} . \times 100$
のようにな

り，それら

の關係は五 に淔線的に 結ばれて特 り, 冷間加 工度が大き いほど, 面 線は漿て 來, その影

響は緩徐に なつて來ることを示しているが，それぞれの值線を延長し て, 高溫加工板再結晶粒客 0 軸 と交わる冷間加工板のそ れが，中間燒鈍しない場合の值とほが一致しているのは面 白い。しかし, 冷間加工度 (f) の逆數と冷間加工板の再 結晶粒度（ ( ）の對數との關係をとると Fig. 7 のよ5 になり，冷間加工板り再結晶粒度は高加工度（87〜95\%) の範溒では冷間加工度の逆數と指數㥛數的關係にあること がわかる

なお，以トの試料について實際に深絞作業を行い，そつ 伸びを測宝するこ Fig.8 のよらになり，冷間加工度

(3) 著者,本誌, 17 (1953), 579.

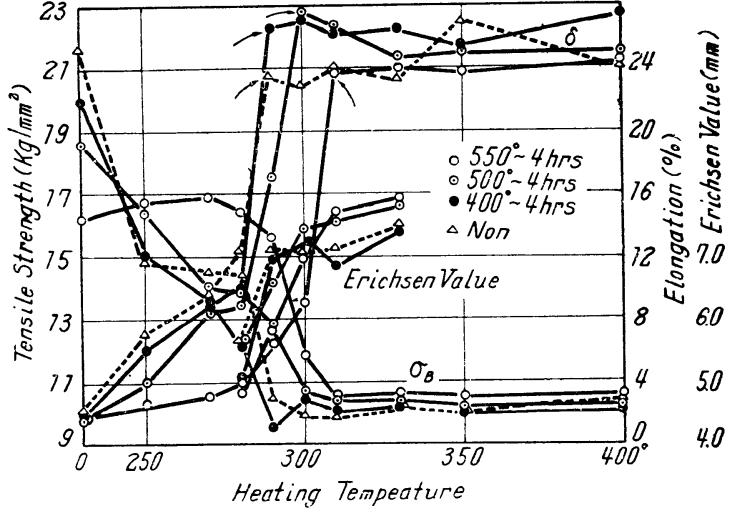

Fig 2 Change of mechanical properties of O $5 \mathrm{~mm}$ sheets upon cold reduction to $93.8 \%$

ると, $0^{\circ}$ と $90^{\circ}$ に earing が發生し、異方性が大きい が，中間燒鈍盈度の高い方で伸びが良好となつていること は, Fig. 2〜4 のエリクセン值の變化と一致して扣り, 引 菲試驗特の伸の變化と一致しない，これは結晶粒の大小と 方向性の影響によるものと考えられる.

熱間加工度が大きく，冷間加工度の小さいことは再結晶 粒度を大きくするが，中間燒鈍を行わないか，むるいは高 溫度で中閒燒玙すれば，實際製品の傮值を害わない程度に 


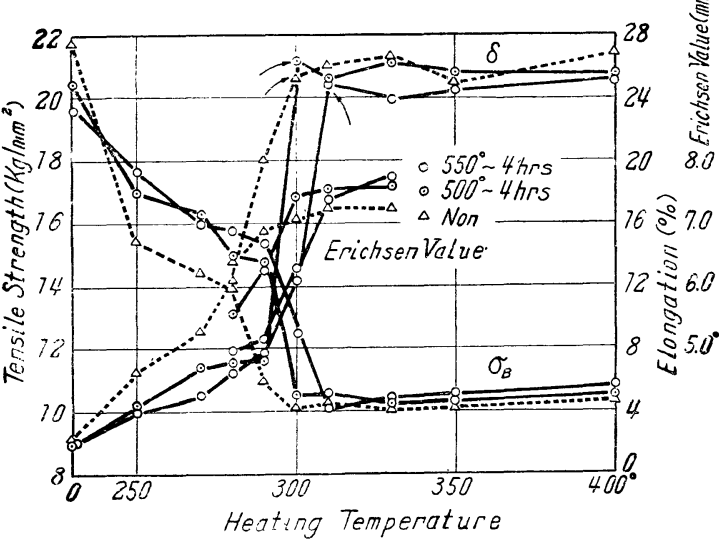

Fig. 3 Change of mechanical procerties of $0.5 \mathrm{~mm}$ sheets upon cold reduction to $91.7 \%$.

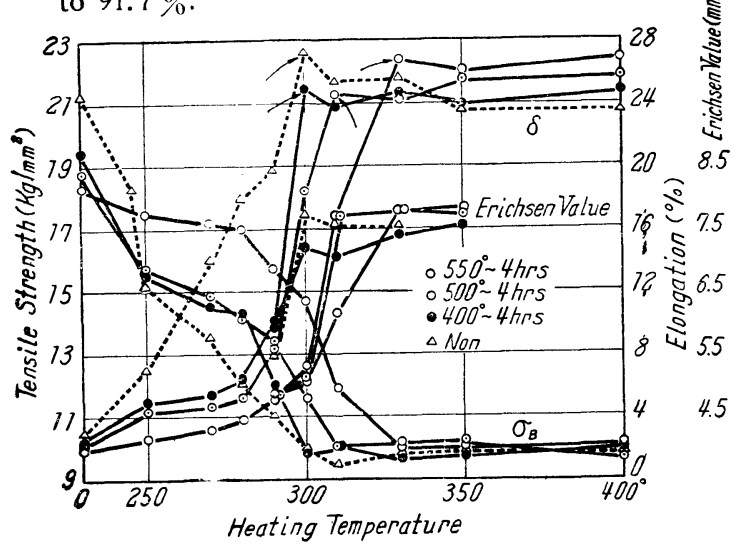

Fig. 4 Change of mechanical prpperties at $0.5 \mathrm{~mm}$ sheets upon cold reduction to $87.5 \%$.

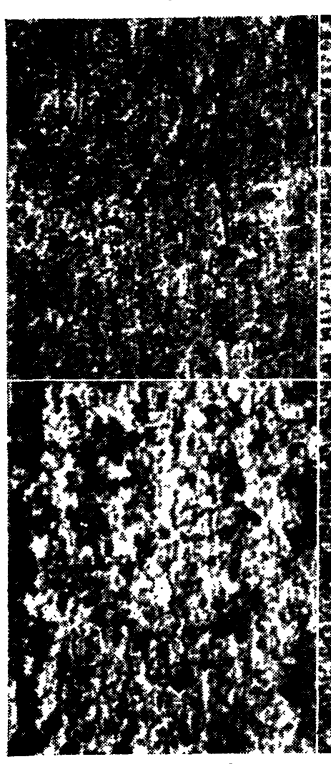

Cold reduction $87.5 \%$

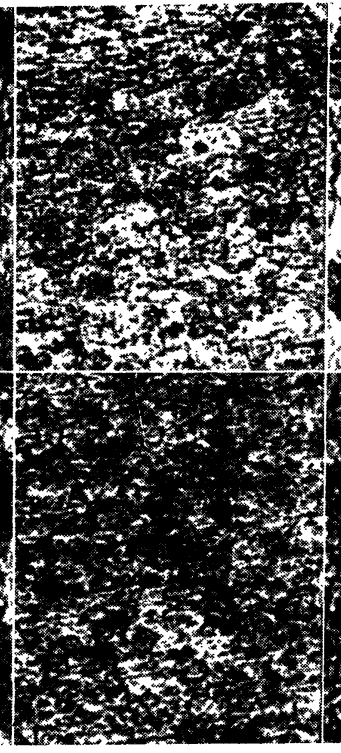

Cold reduction $91.7 \%$
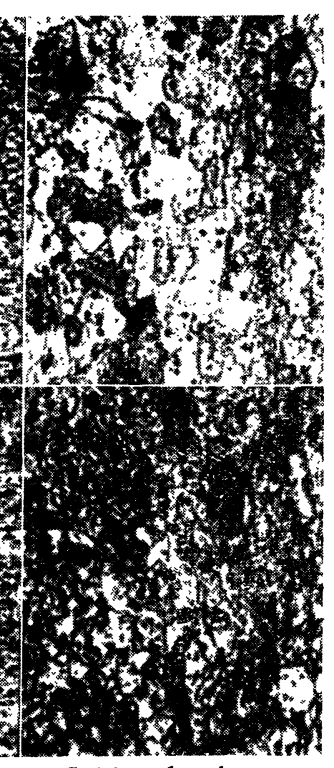

Cold reduction $93.8 \%$
Above $=$ Non interval heating Under $=$ Interval heating at $400^{\circ}$ Photo. 3 Recrystallized microstructure at $350^{\circ} . \times 100$

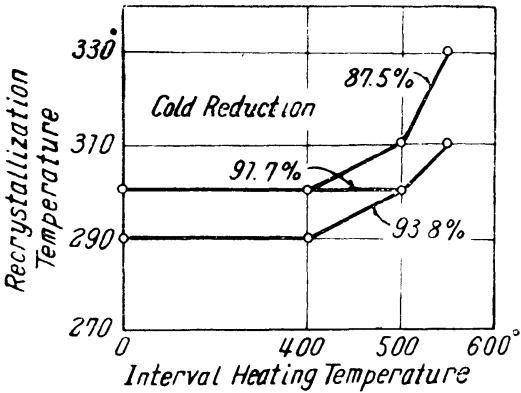

Fig. 5 Relation between the recrystallization tenperature and the interval heating temperature.

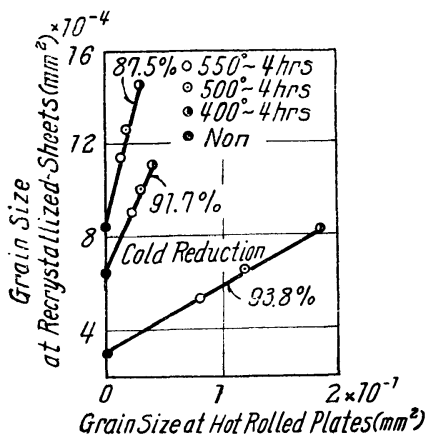

粒度を持つて行 くことが出來, しかも異方性が 少いことは却つ て深絞用板とし ては好ましいと いえよう。

\section{IV. 富驗結 果の考綮}

Fig. 6 Relation between grain size of recrystallized sheets $(0.5 \mathrm{~mm})$ an 1 that of hot rolled plates.

中間燒鈍溫度 が高いほど，熱

間加工後の再結 晶粒が小さくなることは本文でも述べたように，加熱 速度が大になること〉，再結晶粒が再結晶溫度に挍近 して加熱するほど粗大となるといら從來の結果から說 明出來る。

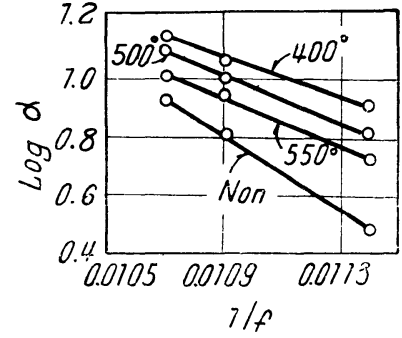

Fig. 7 Relation between $\log \alpha$ and $1 / f$.

しかし，冷間加工前の結晶粒が大きい ほど，冷間加工後の再結昆粒が大さくな り，またその時の再結晶温峑が低下゙す といらことは簡單に說明することは出來 ないする知机ない.たら゙し，F hoto.1 を見ればわかるように（殊に熱間加工度 の低いNo，1〜4で極めて昭睹に識別 される),中間加熱溫度が高いほど第二相 成分化合物が擴散によつて均一に分散さ れるといらことにも一つの原因があるよ 
5に思われる. 寸なわち, 第二相成分の均一分散は加工 歪滀積に對して均一度を高めることになり, 從つて再結晶

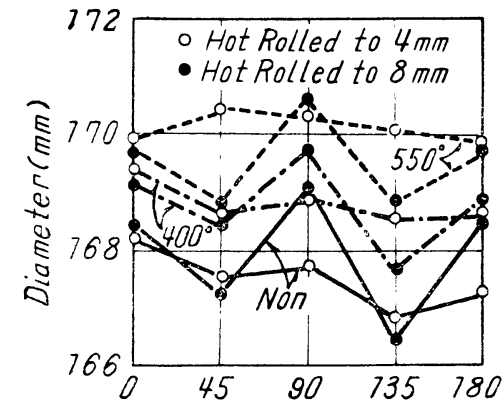

Angle to Rolling Direction

Fig. 8 Change of elongation by deep drawing test.
溫度を上昇せ しめて, しか 6再結晶粒度 を微細にする といら現象が 矛盾せずに解 䆁出來るよう にも考えられ 万.

他方，中間 加熱によつて 冷間加工の影
響が完全に消失し，同一狀態に到達 (Fig. 1 の結果がこ のこと對應すると考えられる）するものとすれば，冷間 加工後に得られる機峨的性質もほ心゙同程度の值を示すのが 本當であろち. しかし，Fig. 2〜4 からわかるよりにそれ らの值には可成りの相違があり, 中間加熱溫度の高い場合 の抗張力が低くなつている. このことは從つて（熱間加工 時の加工歪の影響が残つていないと考えられる故）材料內 部の組織的相違に原因していることを示している. 勿論, 結晶粒が大きいほど冷間加工による加工歪の分布が粗にな り, その高低の差も大きくなることは當然であるから, 再
結晶現象は自然その一次的影響を大きく受けることは首肯 されよう，從つてこの場合には第二相成分分散狀態の相違 は二次的作用を與えるものと考えるのが至當であろち.

\section{V. 總括}

工業周純 $\mathrm{A} 1$ について中間加熱の冷間加工板の再結晶現 象におよぼす影響を檢討した。

（1）熱間加工度が小さいほど，熱間加工後に挌ける板の 再結晶粒度が大きくなる.（2）熱間加工後の再結晶粒度は 加熱溫度が高いほ，ど微細となる．これは加熱速度の影響 と加熱溫度が再結晶溫度に近いほど粗大となるということ から說明されるとした。（3）冷間加工度が大きいほど，再 結晶溫度は低溫となるが，同一加工度の場合には中間加熱 溫度が高い力で再結晶溫度が高くなる.（4）冷間加工前の 結晶粒度が細い方が再結晶粒度を微細にし，また高加工度 の範圍では再結晶粒度は冷間加工度の逆數と指數㥛數的關 係にある. (5) 熱間加工度が大きく, 冷間加工度の小さい 万が異方性が少い，また，引張りによる伸とエリクセン値 とは必ずしも一致せず，エセクセン值におよぼす結晶粒度 の影響も見逃せない（6）冷間加工度が大さいほど，中間 加熱溫度の再結晶粒度に牤よぼす影響が総徐となる。

終りに，本實驗を熱心に逐行した野原修君の勞に對して 感謝の箩を表します。 